\title{
Chronic Antidepressant Administration Increases the Expression of cAMP Response Element Binding Protein (CREB) in Rat Hippocampus
}

\author{
Masashi Nibuya, Eric J. Nestler, and Ronald S. Duman \\ Laboratory or Molecular Psychiatry, Departments of Psychiatry and Pharmacology, Yale University School of Medicine, \\ Connecticut Mental Health Center, New Haven, Connecticut 06508
}

The present study demonstrates that chronic, but not acute, administration of several different classes of antidepressants, including serotonin- and norepinephrine-selective reuptake inhibitors, increases the expression of cAMP response element binding protein (CREB) mRNA in rat hippocampus. In contrast, chronic administration of several nonantidepressant psychotropic drugs did not influence expression of CREB mRNA, demonstrating the pharmacological specificity of this effect. In situ hybridization analysis demonstrates that antidepressant administration increases expression of CREB mRNA in CA1 and CA3 pyramidal and dentate gyrus granule cell layers of the hippocampus. In addition, levels of CRE immunoreactivity and of CRE binding activity were increased by chronic antidepressant administration, which indicates that expression and function of CREB protein are increased along with its mRNA. Chronic administration of the phosphodiesterase (PDE) inhibi- tors rolipram or papaverine also increased expression of CREB mRNA in hippocampus, demonstrating a role for the cAMP cascade. Moreover, coadministration of rolipram with imipramine resulted in a more rapid induction of CREB than with either treatment alone. Increased expression and function of CREB suggest that specific target genes may be regulated by these treatments. We have found that levels of brain-derived neurotrophic factor (BDNF) and trkB mRNA are also increased by administration of antidepressants or PDE inhibitors. These findings indicate that upregulation of CREB is a common action of chronic antidepressant treatments that may lead to regulation of specific target genes, such as BDNF and trkB, and to the long-term effects of these treatments on brain function.

Key words: CAMP; desipramine; imipramine; fluoxetine; sertraline; ECS; tranylcypromine; rolipram; brain-derived neurotrophic factor
Preclinical and clinical studies support the hypothesis that the brain pathways that contain serotonin $(5-\mathrm{HT})$ and norepinephrine (NE) play a role in the therapeutic action of antidepressant treatments, and possibly in the manifestation of certain symptoms of depression (Heninger and Charney, 1987; Maes and Meltzer, 1995; Schatzberg and Schildkraut, 1995). However, these studies have failed to identify a common action of antidepressants at the level of these neurotransmitters or their receptors. This is not surprising given that the different classes of antidepressants currently available, including selective and nonselective 5-HT and $\mathrm{NE}$ reuptake blockers, have different effects on levels of these two monoamines. Moreover, elevation of 5-HT and NE levels in response to acute drug exposure is not consistent with the time course for the therapeutic action of antidepressant treatments (i.e., several weeks), suggesting that thcir mcchanism of action involves neuronal adaptations to these acute effects (Heninger and Charney, 1987; Sulser, 1989; Hudson et al., 1993; Duman et al., 1994).

Another explanation to account for the action of different types of antidepressants is that there is a common, intracellular adaptation beyond the levels of 5-HT and NE and their receptors (Sulser, 1989; Hudson et al., 1993; Duman et al., 1994). In this

Received Nov. 29, 1995; revised Jan. 4, 1996; accepted Jan. 10, 1996.

This work was supported by Public Health Service Grants MH45481, MH53199, and 2 PO1 MH25642, and by a Veterans Administration National Center Grant for PTSD, VA Medical Center.

Correspondence should be addressed to Dr. Ronald S. Duman, Connecticut Mental Health Center, 34 Park Street, New Haven, CT 06508.

Copyright (1) 1996 Socicty for Neuroscience $0270-6474 / 96 / 162365-08 \$ 05.00 / 0$ case, regulation of monoamine levels and receptors may represent initial effects that subsequently lead to regulation of postreceptor pathways and genes that ultimately mediate the therapeutic action of antidepressants. One candidate postreceptor target that could be regulated by both 5-HT and NE and thereby mediate longterm adaptations in response to diverse antidepressant treatments is the nuclear transcription factor cAMP response element binding protein (CREB). The function of CREB is increased by activation of the CAMP cascade and phosphorylation of CREB by cAMP-dependent protein kinase (PKA) (Meyer and Haebner, 1993; Ghosh and Greenberg, 1995). In this way, CREB could be activated by $5-\mathrm{HT}$ and NE receptors that directly stimulate cAMP production (c.g., 5- $\mathrm{HT}_{4,6.7}$ or $\beta$-adrenergic receptors). In addition, the function of CREB may be regulated by other 5-HT or NE receptors (e.g., 5- $\mathrm{HT}_{2 \mathrm{~A}, \mathrm{C}}$ and $\alpha_{1}$-adrenergic receptors) that lead to stimulation of $\mathrm{Ca}^{2+}$-dependent protein kinases (Meyer and Haebner, 1993; Ghosh and Greenburg, 1995).

A role for the cAMP cascade in the long-term actions of antidepressant treatments is supported by previous studies demonstrating that chronic antidepressant treatments regulate levels of adenylyl cyclase and PKA in the brain (Menkes et al., 1983; Nestler et al., 1989; Perez et al., 1989; Ozawa and Rasenick, 1991). To examine a role for CRFB, the influence of chronic administration of several different classes of antidepressants on expression of CREB in hippocampus was examined. Hippocampus has been implicated in both the treatment and pathophysiology of depression and other stressrelated psychiatric disorders (Heninger and Charney, 1987; Jacobson and Sapolsky, 1991; Young et al., 1991; Bremner et al., 1995; Duman et al., 1995). The results demonstrate that chronic administration of 
several different types of antidepressants, but not nonantidepressant psychotropic drugs, increases the expression of CREB in rat hippocampus.

Increased expression of CREB would be expected to alter the expression of specific target genes. Among the many potential larget genes regulated by CREB are those for brain-derived neurotrophic factor (BDNF) and its receptor, trkB (Condorelli et al., 1994; Ghosh et al., 1994; Duman et al., 1995). We have reported that chronic antidepressant administration increases levels of BDNF and trkB in rat hippocampus (Nibuya et al., 1995). Moreover, several lines of behavioral and neurochemical evidence support a role for BDNF in the treatment, and possibly even the pathophysiology, of depression (Suiciak et al., 1994a; Duman et al., 1995; Nibuya et al., 1995; Smith et al., 1995). In the present study, we demonstrate that the regional distribution and time course for induction of CREB correspond to that for BDNF and trkB. In addition, we demonstrate that sustained elevation of cAMP, via chronic administration of a phosphodiesterase (PDE) inhibitor, increases the expression of CREB, as well as BDNF and trkB, and facilitates the action of antidepressants on expression of these proteins.

\section{MATERIALS AND METHODS}

Animals and treatment paradigms. Male Sprague-Dawley rats (150-200 gm, CAMM, Wayne, NJ) were group housed and maintained on a $12 \mathrm{hr}$ light/dark cycle with food and water freely available. All treatments were according to standard protocols as described previously (Nibuya et al., 1995). Rats were administered (once daily) electroconvulsive seizure (ECS) via earclip electrodes $(50 \mathrm{~mA}, 0.3 \mathrm{sec})$ or received sham treatment (handled identically as those that received ECS, but without electrical stimulation). For drug treatments, groups of rats werc administered tranylcypromine $(7.5 \mathrm{mg} / \mathrm{kg}$ for $7 \mathrm{~d}$ then $10 \mathrm{mg} / \mathrm{kg}$ for $14 \mathrm{~d})$, imipramine $(15 \mathrm{mg} / \mathrm{kg})$, desipramine $(15 \mathrm{mg} / \mathrm{kg})$, sertraline $(10 \mathrm{mg} / \mathrm{kg})$, fluoxetine $(5$ $\mathrm{mg} / \mathrm{kg}$ ), haloperidol (2 $\mathrm{mg} / \mathrm{kg}$ ), cocaine (15 $\mathrm{mg} / \mathrm{kg}$ ), rolipram (2 or 10 $\mathrm{mg} / \mathrm{kg}$, as indicated), papaverine $(10 \mathrm{mg} / \mathrm{kg})$, or vehicle $(0.9 \%$ saline for all treatments, except rolipram, for which the vehicle was $1 \%$ dimethylsulfoxide, injected in a volume of $0.25 \mathrm{ml}$ ) once daily for $21 \mathrm{~d}$ via intraperitoneal injection and killed $18 \mathrm{hr}$ after the last treatment. For morphine treatment, rats were administered morphine pellets $(75 \mathrm{mg}$ pellets, s.c.) once daily for $5 \mathrm{~d}$ or received the same sham treatment (sham surgery without pellet implantation).

Brains were removed and frozen immediately for in situ hybridization, or sections of hippocampus were dissected for RNA extraction and Northern blot analysis, or gel-shift analysis, as described below. All animal use procedures were in strict accordance with the National Institutes of Health Guide for the Care and Use of Laboratory Animals and were approved by the Yale Animal Care and Use Committee. The drugs used for these studies were obtained from the following sources: tranylcypromine, imipramine, desipramine, papaverine, and haloperidol were purchased from Sigma (St. Louis, MO); fluoxetine was provided by Lilly (Indianapolis, IN); sertraline was provided by Pfizer (Groton, CT); rolipram was provided by Schering (Germany); and morphine and cocaine were obtained from the National Institute on Drug Abuse (Baltimore, MD).

Northern blot analysis. Total RNA was isolated from sections of hippocampus by the guanidine isothiocyanate/cesium chloride centrifugation method, and levels of CREB, BDNF, and trkB mRNA were determined by Northern blot analysis (Nibuya et al., 1995). CREB (S. E. Hyman, Harvard Medical School), BDNF (Regeneron, Tarrytown, NY), and trkB (The National Cancer Institute, Frederick, MD) cDNA clones were used to generate ${ }^{32} \mathrm{P}$-labeled riboprobes. Briefly, $20 \mu \mathrm{g}$ of total RNA was electrophoresed on a $1 \%$ agarose gel, and the RNA was transferred to nitrocellulose filters. The resulting filters were then incubated with the ${ }^{32} \mathrm{P}$-labeled CREB, BDNF, or trkB riboprobes for $18 \mathrm{hr}$ at $65^{\circ} \mathrm{C}$ and washed in $2 \times \mathrm{SSC}$ (SSC: $0.15 \mathrm{M} \mathrm{NaCl}, 0.015 \mathrm{M}$ sodium citrate, $\mathrm{pH} 7.0$ ), $0.1 \%$ SDS at $65^{\circ} \mathrm{C}$ for $30 \mathrm{~min}$, and then twice in $0.2 \times$ SSC, $0.1 \%$ SDS at $65^{\circ} \mathrm{C}$ for $60 \mathrm{~min}$. Levels of total RNA for each lane were determined by reprobing the nitrocellulose filters with a ${ }^{32} \mathrm{P}$-labeled cyclophilin cDNA probe that was radiolabeled using a random prime kit (Stratagene, La Jolla, CA). The radiolabeled mRNA bands were visualized by autoradiography and quantified with a GSXL laser densitometer. The levels of
CREB, BDNF, or trkB mRNA were normalized to cyclophilin mRNA levels to account for differences in the amount of RNA per lane.

In situ hybridization analysis. Analysis of CREB, BDNF, and trkB mRNA by in situ hybridization was conducted as described previously by this laboratory (Nibuya et al., 1995). Coronal brain sections were hybridized with ${ }^{35} \mathrm{~S}$-labeled $\mathrm{CREB}, \mathrm{BDNF}$, or trkB riboprobes $\left(10^{6} \mathrm{cpm} / \mathrm{sec}-\right.$ tion) for $18 \mathrm{hr}$ at $55^{\circ} \mathrm{C}$ in buffer containing $50 \%$ formamide, $0.6 \mathrm{M} \mathrm{NaCl}$ $10 \mathrm{~mm}$ Tris, $1 \times$ Denhardt's solution, $2 \mathrm{~mm}$ EDTA, $10 \mathrm{~mm}$ dithiothreitol, $10 \%$ dextran sulfate, $50 \mathrm{\mu g} / \mathrm{ml}$ salmon sperm DNA, and $250 \mathrm{mg} / \mathrm{ml}$ tRNA The sections were washed in $2 \times \mathrm{SSC}$ at $25^{\circ} \mathrm{C}$ and then treated with 20 $\mu \mathrm{g} / \mathrm{ml} \mathrm{RNase}$ A for $45 \mathrm{~min}$ in $0.5 \mathrm{M} \mathrm{NaCl}, 10 \mathrm{~mm}$ Tris, and $1 \mathrm{~mm}$ EDTA The sections were then washed twice in $0.2 \times \mathrm{SSC}$ at $55^{\circ} \mathrm{C}, 30$ min per wash. The sections were dried, exposed to Hyperfilm (Amersham, Arlington Heights, IL), and subsequently counterstained with cresyl violet to allow alignment with the autoradiogram. The specificity of the hybridization was confirmed by demonstrating that ${ }^{35} \mathrm{~S}$-labeled sense CREB, $\mathrm{BDNF}$, or trkB riboprobes did not yield any significant hybridization (data not shown).

Gel-shift analysis. Extracts of hippocampus from control or antidepressant-treated rats were prepared for CRE gel-shift analysis as described previously (Widnell et al., 1994). The somatostatin consensus CRE (GATCGGCTGACGTCAGAG) was used for gel-shift analysis. Double-stranded DNA was labeled using a fill-in reaction with [ $\left.{ }^{32} \mathrm{P}\right] \mathrm{dGTP}$ and $\left[{ }^{32} \mathrm{P}\right] \mathrm{dTTP}$ and Klenow DNA polymerase to a specific activity of $\sim 8$ $\times 10^{8} \mathrm{cpm} / \mu \mathrm{g}$ DNA. Labeled DNA was incubated with $\sim 20 \mu \mathrm{g}$ of extract protein for $20 \mathrm{~min}$ at $20^{\circ} \mathrm{C}$. The samples were then electrophoresed $(150$ V) for $2 \mathrm{hr}$ on a nondenaturing $6 \%$ acrylamide: $0.16 \% \mathrm{~N}, \mathrm{~N}^{\prime}$. methylenebisacrylamide gel containing $25 \mathrm{~mm}$ Tris-borate buffer, $\mathrm{pH} 8.3$, $1 \mathrm{mM}$ EDTA, and $1.6 \%$ glycerol. The resulting gels were dried and subjected to autoradiography. Levels of CRE binding were quantified by densitometry. The specificity of the CRE binding was determined by competition with different concentrations (3-100 $\mathrm{ng}$ ) of cold CRE, mutated CRE (GATCGGCTGACGTCTGAG: mutated nucleotide is in bold), or human metalliothionein AP-1 (TCGACGGGACTCAGCGCGC) oligonucleotides: only unlabeled CRE oligonucleotide effectively competed with labeled CRE binding (data not shown). For supershift analysis, $1 \mu 1$ of anti-CREB (Upstate Biochemical, Lake Placid, NY) or anti-CREM (Santa Cruz Biotechnology, Santa Cruz, CA) antibody was incubated with cell extracts for $18 \mathrm{hr}$ at $4^{\circ} \mathrm{C}$ before the addition of labeled probe.

Data analysis. Levels of CREB, BDNF, and trkB mRNA were determined by outlining the band on Northern blots or the regions of interest on in situ hybridization sections, which were then quantified on a Macintosh-based National Institutes of Health Image analysis program, version 1.52; an equivalent area on each Northern blot or brain section was outlined for the various samples. ${ }^{14} \mathrm{C}$ step standards were used to verify the linearity of densitometry. For in situ hybridization sections, the following regions were analyzed: dentate gyrus granule cell layer, CA3 and CA1 pyramidal cell layers, and piriform cortex pyramidal cell layer. For each animal, both sides of three individual brain sections werc analyzed, for a total of six determinations, and the mean was determined. The results from several animals were then subjected to statistical analysis. Experiments containing groups of three rats or more (see treatment paradigms above) were subjected to ANOVA, with a significance level of $<0.05$, and Fisher's post-hoc test. Experiments containing two groups were subjected to Student's $t$ test, with significance determined at the $<0.05$ level

\section{RESULTS}

Chronic (21 d) administration of several different types of antidepressant drugs significantly increased levels of CREB mRNA in rat hippocampus (Figs. 1, 2). The antidepressant drugs tested included desipramine (a selective NE reuptake inhibitor), imipramine (a nonselective 5-HT and NE reuptake inhibitor), tranylcypromine (a monoamine oxidase inhibitor), and sertraline and fluoxetine (two 5-HT selective reuptake inhibitors). Chronic administration $(10 \mathrm{~d})$ of FCS, a treatment for which the relevant acute action is unknown, also increased levels of CREB mRNA in hippocampus. In contrast, chronic administration of several nonantidepressant drugs did not influence expression of CREB mRNA in this brain region, demonstrating the pharmacological specificity of this effect for antidepressant treatments (Fig. 1): the drugs tested included morphine (an opiate agonist), cocaine (a 


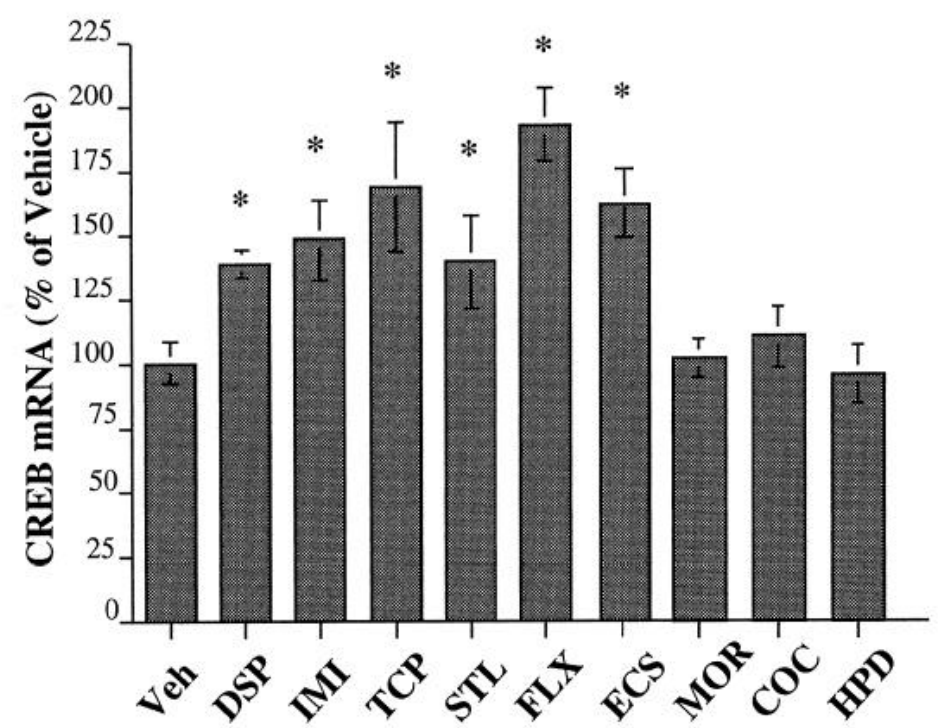

Figure 1. Chronic antidepressant treatment increases levels of CREB mRNA in hippocampus. Desipramine (DSP), imipramine (IMI), tranylcypromine $(T C P)$, sertraline $(S T L)$, fluoxetine $(F L X)$, electroconvulsive seizure $(E C S)$, morphine $(M O R)$, cocaine $(C O C)$, and haloperidol $(H D P)$ were administere chronically, and CREB and cyclophilin mRNA levels in hippocampus were determined by Northern blot analysis. Levels of CREB mRNA were quantitated by densitometry and normalized to cyclophilin mRNA levels. The results are expressed as percent of control and are the mean \pm SEM of $5-6$ rats for each treatment group. ${ }^{*} p<0.05$ compared with vehicle control (ANOVA and Fisher's test).

monoamine reuptake inhibitor and psychostimulant), and haloperidol (a dopamine $\mathrm{D}_{2}$ receptor antagonist and antipsychotic). Chronic antidepressant administration did not influence levels of mRNA for one of the PKA catalytic subunits, PKA-C $\alpha$, demonstrating that there is not a general increase in expression of cAMP cascade proteins in response to antidepressant treatment (data not shown).

Increased expression of CREB mRNA was observed after $10 \mathrm{~d}$, but not $3 \mathrm{~d}$, of fluoxetine or tranylcypromine administration, demonstrating that upregulation of CREB is dependent on repeated antidepressant treatment (Fig. 2). In addition, acute administration of desipramine, imipramine, sertraline, or ECS did not significantly increase levels of CREB mRNA [102 $\pm 8,115 \pm$ $5,110 \pm 4$, and $115 \pm 9 \%$ of control, respectively (mean \pm SEM); $n=6]$.

We have reported that chronic administration of several antidepressants (i.e., sertraline, tranylcypromine, desipramine, or ECS), but not nonantidepressants (i.e., morphine, cocaine, or haloperidol), increases the expression of BDNF and trkB mRNA in hippocampus (Nibuya et al., 1995). Moreover, expression of BDNF and trkB is reported to be increased by activation of the cAMP cascade (Condorelli et al., 1994; Ghosh et al., 1994), suggesting that the induction of CREB could contribute to increased expression of BDNF and trkB in response to chronic antidepressant treatments. This possibility is supported by the temporal properties of $\mathrm{BDNF}$ and trkB regulation: the time course for induction of CREB was similar to that for induction of BDNF and trkB mRNA in response to these treatments (Fig. 2).

The regional distribution of CREB mRNA expression was examined further by in situ hybridization analysis (Fig. 3). Chronic ECS, fluoxetine, or tranylcypromine administration significantly increased levels of CREB mRNA in the dentate gyrus granule cell layer, and CA 3 and CA1 pyramidal cell layers in hippocampus
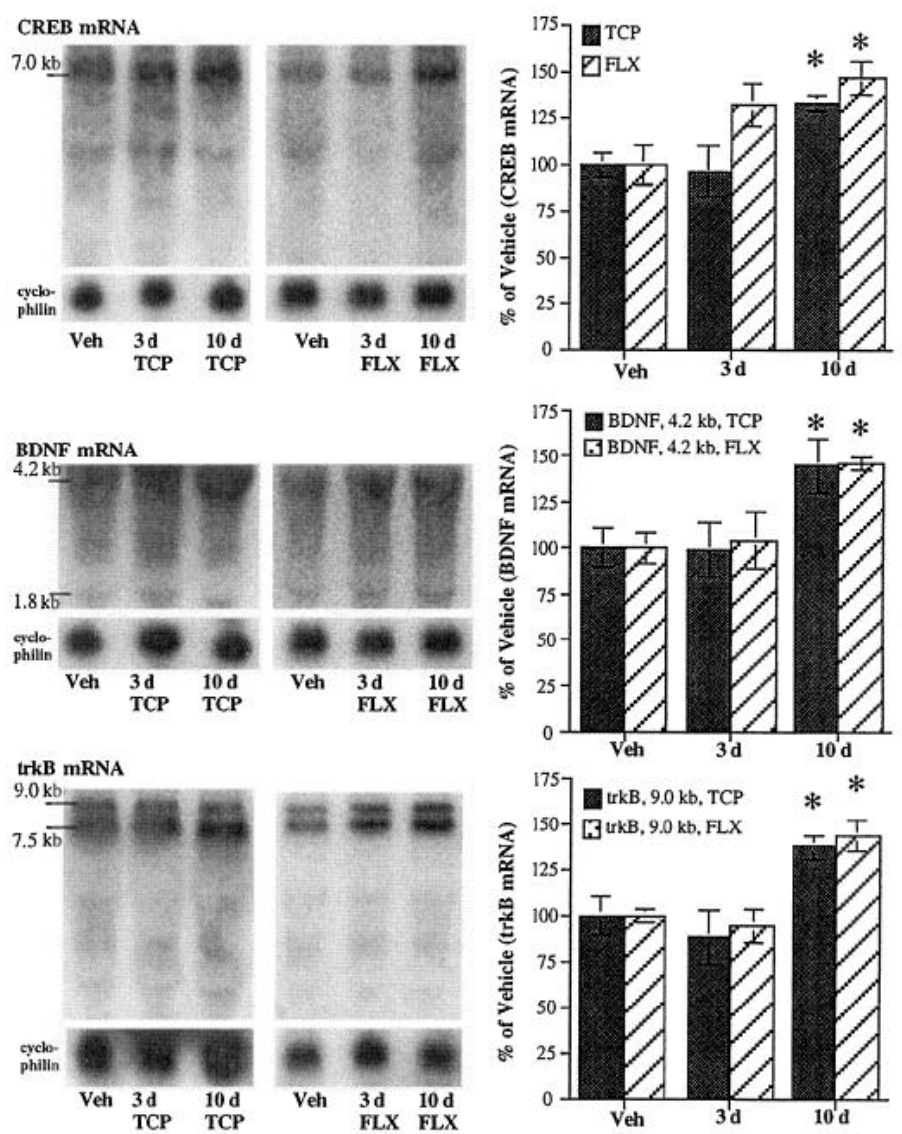

Figure 2. Time course for antidepressant regulation of CREB, BDNF, and trkB mRNA in hippocampus. Fluoxetine $(F L X)$ or tranylcypromine $(T C P)$ was administered for the times indicated, and levels of CREB, BDNF, and trkB mRNA were determined by Northern blot analysis. Levels of CREB mRNA were quantitated by densitometry and normalized to cyclophilin mRNA levels. Fluoxetine and tranylcypromine administration also increased levels of the $1.8 \mathrm{~kb}$ BDNF mRNA band (144 \pm 7 and $150 \pm 4 \%$ of vehicle, respectively) and the $7.5 \mathrm{~kb}$ trkB mRNA band (147 \pm 8 and $152 \pm 6 \%$ of control, respectively). Both the 4.4 and the $1.8 \mathrm{~kb}$ BDNF transcripts encode full-length BDNF; the $9.0 \mathrm{~kb}$ trkB transcript encodes a full-length trkB receptor, and the $7.5 \mathrm{~kb}$ trkB mRNA encodes truncated receptor lacking the tyrosine kinase domain. The results are expressed as percent of control and are the mean \pm SEM of $4(T C P)$ or $6(F L X)$ rats. ${ }^{*} p<0.05$ compared with vehicle control (ANOVA and Fisher's test).

(Fig. 3). We have reported previously that chronic ECS increases or prolongs the expression of BDNF and trkB mRNA in these same cell layers of hippocampus (Nibuya et al., 1995). Here we demonstrate that chronic fluoxetine or tranylcypromine administration also increases the expression of BDNF and trkB mRNA in these three hippocampal cell layers (Fig. 3). In contrast, levels of CREB, BDNF, and trkB mRNA were not significantly influenced in the pyramidal cell layer of piriform cortex (Fig. 3). These findings are consistent with the hypothesis that the induction of CREB is related to the upregulation of BDNF and trkB.

Chronic ECS or fluoxetine administration significantly increased levels of CRE binding activity in extracts of hippocampus, determined by gel-shift analysis (Fig. 4). The levels of CRE binding were $134 \pm 5$ and $127 \pm 4 \%$ of control for fluoxetine and ECS treatments, respectively (mean \pm SEM, $n=5, p<0.05$, Student's $t$ test). In contrast, acute ECS or fluoxetine treatment did not significantly influence levels of CRE binding [102 \pm 6 and $94 \pm 3 \%$ of control, respectively (mean $\pm \mathrm{SEM}$ ); $n=5$ ]. The 


\section{CREB mRNA}

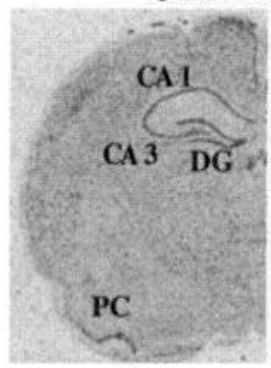

Sham

\begin{tabular}{lcc} 
CREB mRNA & Sham & ECS \\
\hline $\begin{array}{l}\text { Dentate gyrus } \\
\text { granule cell layer }\end{array}$ & $100.0 \pm 5.7$ & $235.4 \pm 15.2^{*}$
\end{tabular}

CA3 pyramidal cell layer

CA1 pyramidal cell layer

Piriform cortex layer 2

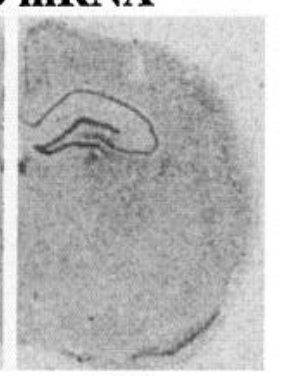

ECS

$100.0 \pm 5.9 \quad 141.3 \pm 12.3 *$

$100.0 \pm 2.6 \quad 151.2 \pm 3.8^{*}$

$100.0 \pm 15.6 \quad 98.8 \pm 7.6$



\section{BDNF mRNA}

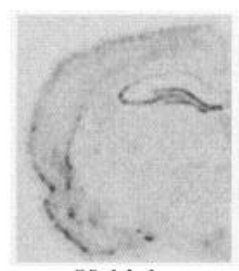

Vehicle

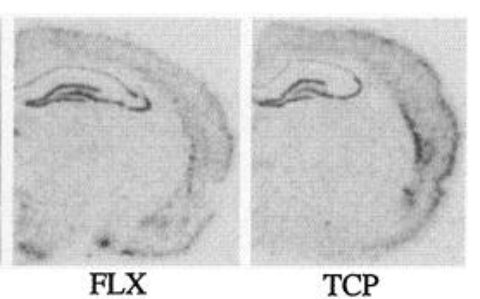

trkB mRNA

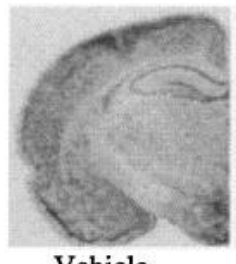

Vehicle

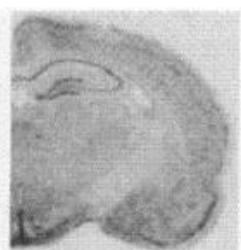

FLX

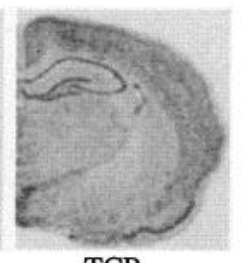

TCP

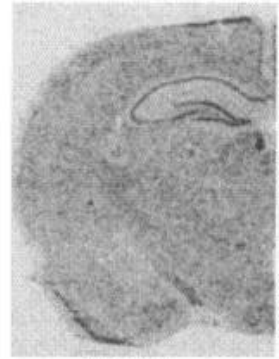

Vehicle

CREB mRNA

Dentate gyrus

granule cell layer

CA3 pyramidal

cell layer

CA1 pyramidal

cell layer

Piriform cortex

layer 2

\section{CREB mRNA}
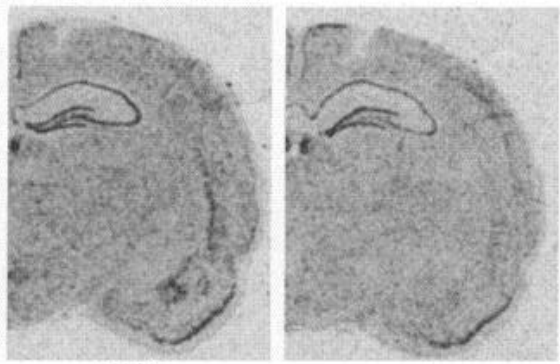

FLX

TCP

\begin{tabular}{lccc}
\hline BDNF mRNA & Vehicle & FLX & TCP \\
\hline $\begin{array}{l}\text { Dentate gyrus } \\
\text { granule cell layer }\end{array}$ & $100 \pm 5$ & $160 \pm 14^{*}$ & $137 \pm 18^{*}$ \\
$\begin{array}{l}\text { CA3 pyramidal } \\
\text { cell layer }\end{array}$ & $100 \pm 4$ & $153 \pm 16^{*}$ & $146 \pm 19^{*}$ \\
$\begin{array}{l}\text { CA1 pyramidal } \\
\text { cell layer }\end{array}$ & $100 \pm 3$ & $261 \pm 39^{*}$ & $175 \pm 22^{*}$ \\
$\begin{array}{l}\text { Piriform cortex } \\
\text { layer 2 }\end{array}$ & $100 \pm 7$ & $102 \pm 10$ & $101 \pm 9$ \\
\hline
\end{tabular}

\begin{tabular}{lccc}
\multicolumn{1}{c}{ trkB mRNA } & Vehicle & FLX & TCP \\
\hline $\begin{array}{l}\text { Dentate gyrus } \\
\text { granule cell layer }\end{array}$ & $100 \pm 8$ & $136 \pm 4^{*}$ & $143 \pm 6^{*}$ \\
$\begin{array}{l}\text { CA3 pyramidal } \\
\text { cell layer }\end{array}$ & $100 \pm 7$ & $154 \pm 13^{*}$ & $145 \pm 10^{*}$ \\
$\begin{array}{l}\text { CA1 pyramidal } \\
\text { cell layer }\end{array}$ & $100 \pm 7$ & $140 \pm 13^{*}$ & $163 \pm 8^{*}$ \\
$\begin{array}{l}\text { Piriform cortex } \\
\text { layer 2 }\end{array}$ & $100 \pm 8$ & $90 \pm 10$ & $109 \pm 11$ \\
\hline
\end{tabular}

Figure 3. In situ hybridization analysis of CREB, BDNF, and trkB mRNA: regulation by antidepressant treatment. ECS (10 d), fluoxetine (21 d), or tranylcypromine $(21 \mathrm{~d})$ was administered, and brain sections were subjected to in situ hybridization analysis using ${ }^{35}$ S-labeled CREB, BDNF, and trkB riboprobes. Representative autoradiograms for each of the conditions are shown. The dentate gyrus granule cell layer (DG), CA3 pyramidal cell layer $(C A 3), C A 1$ pyramidal cell layer $(C A 1)$, and piriform cortex $(P C)$ are indicated. Levels of mRNA were quantitated by densitometry of in situ hybridization autoradiograms. Results are expressed as percent of control and are the mean \pm SEM of $3(E C S)$ or $6(F L X$ and $T C P)$ separate animals. ${ }^{*} p<0.05$ compared with control (Student's $t$ test for ECS; ANOVA and Fisher's test for TCP and FLX).

presence of CREB in the CRE binding complex was determined by gel-supershift analysis. Preincubation of hippocampal extracts with anti-CREB antibody completely disrupted the CRE band in both sham- and ECS-treated samples (Fig. 4). In contrast, preincubation with antibody directed against CREM, another transcription factor that specifically binds to the CRE, did not influence levels of the CREB/CRE complex (Fig. 4). The CREM antibody does effectively disrupt a faster migrating CRE binding complex containing CREM isoforms, demonstrating that it is active and specific (Fitzgerald et al., 1995). Competition experiments were also conducted to demonstrate the specificity of our gel-shift assay. The CRE band was completely blocked by addition of unlabeled CRE oligonucleotide, but was not significantly influenced by a mutated CRE (which differed from the consensus CRE by a single base pair) or by an AP-1 oligonucleotide (data not shown). The influence of antidepressant administration on levels of CREB protein in hippocampus was determined by immunohistochemistry. Chronic administration of fluoxetine or ECS also increased levels of CREB immunoreactivity in the dentate gyrus granule cell layer, and CA 3 and CA1 pyramidal cell layers of hippocampus. This is attributable to an increase in the level of CREB immunoreactivity per cell rather than to an increase in the number of CREB-immunoreactive cells. Upregulation of CREB immunoreactivity provides further evidence that upregulation of 


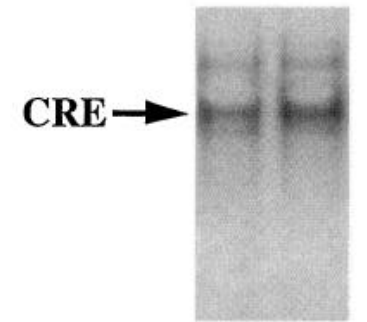

C FLX

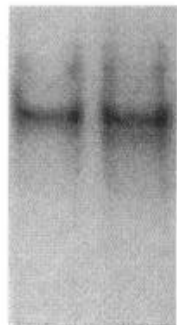

C ECS

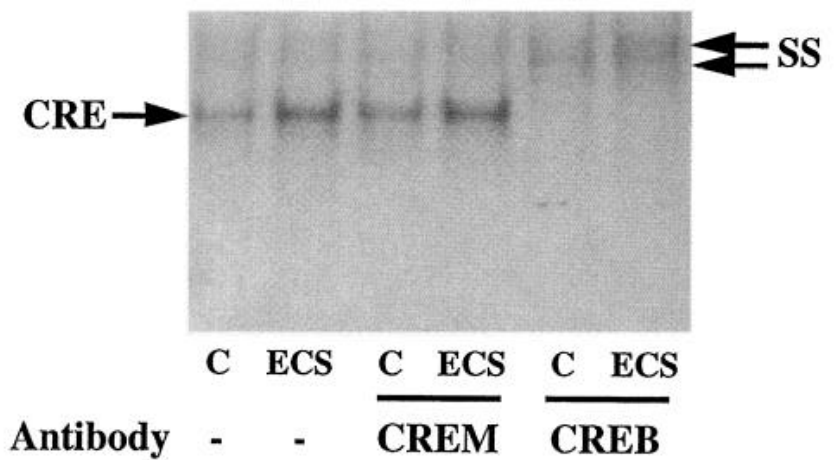

Figure 4. Chronic antidepressant administration increases levels of CRE binding activity in hippocampus. Fluoxetine $(F L X)$ or ECS was administered chronically, and levels of CRE binding were determined by gel-shift analysis. The presence of CREB in the CRE binding complex was demonstrated by gel-supershift analysis. Preincubation of hippocampal extracts with anti-CREB, but not anti-CREM, antibody disrupted the CREbinding complex and resulted in the formation of a supershifted band $(S S)$. Representative autoradiograms are shown for each.

CREB mRNA is accompanied by an increase in levels of CREB protein (Fig. 5).

To examine the role of the cAMP system in regulation of CREB expression, the influence of chronic administration of a PDE inhibitor (i.e., rolipram or papaverine) on levels of CREB mRNA was determined. Chronic administration of rolipram or papaverine significantly increased levels of CREB mRNA in hippocampus (Fig. 6). Upregulation of CREB by these treatments was dependent on chronic administration, because acute administration of these agents did not significantly influence expression of CREB mRNA [100 \pm 5 and $104 \pm 6 \%$ of control (mean \pm SEM); $n=6$ ]. These treatments also increased levels of BDNF and trkB mRNA in hippocampus, further supporting a role for cAMP and CREB in the induction of these mRNAs in response to antidepressant treatment (Fig. 6). We also examined the influence of coadministration of rolipram and imipramine for $7 \mathrm{~d}$ on levels of CREB and BDNF mRNA. At this time point, there was no significant effect of either treatment alone, but coadministration BDNF mRNA (Fig. 6). Preliminary results indicate that coadministration of imipramine and rolipram also results in a more rapid upregulation of trkB (data not shown).

\section{DISCUSSION}

The results of the present study demonstrate that chronic antidepressant administration increases the expression of CREB mRNA in rat hippocampus. Upregulation of CREB mRNA was observed after chronic, but not acute, administration, consistent with the time course for the therapeutic action of antidepressants. Moreof the two drugs resulted in significant upregulation of CREB and
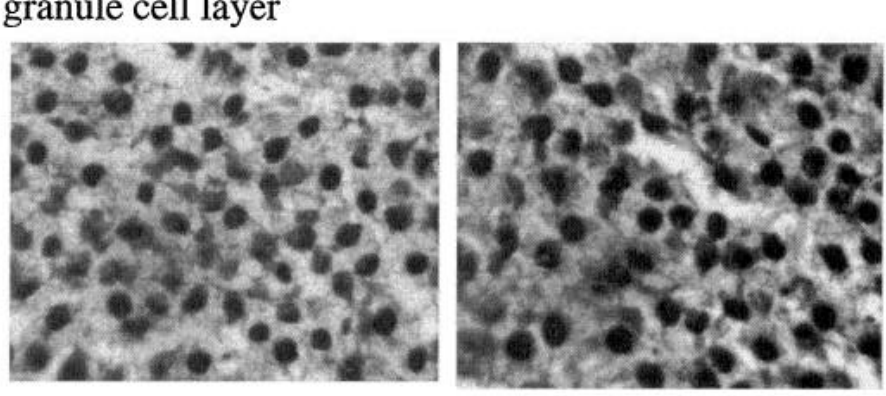

CA1 pyramidal cell layer

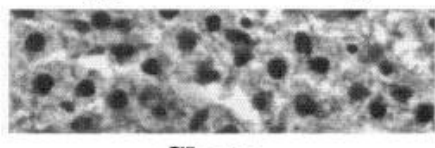

Sham

granule cell layer

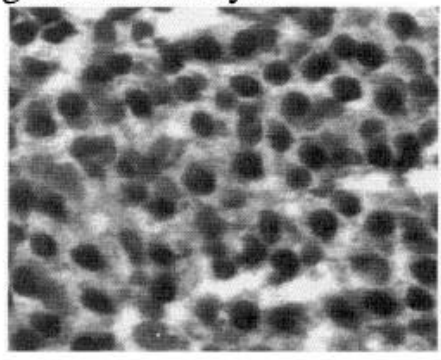

CA1 pyramidal cell layer

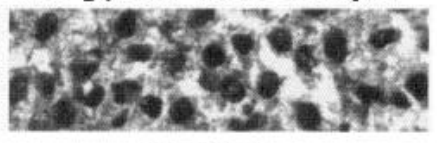

Vehicle
CREB immunoreactivity

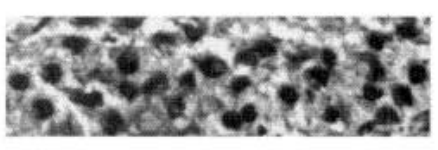

ECS 10 days
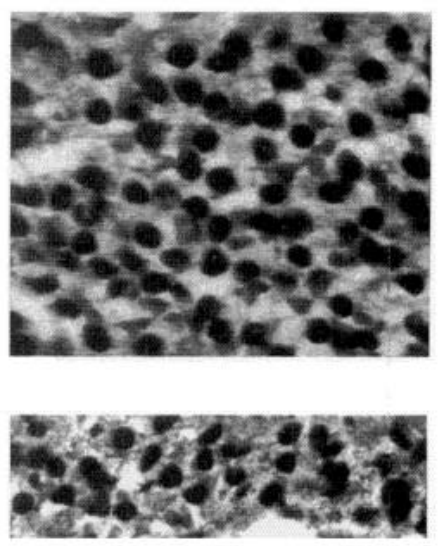

FLX 21 days
Figure 5. Chronic antidepressant treatment increases levels of CREB immunoreactivity in hippocampus. Fluoxetine $(F L X ; 21 \mathrm{~d})$ or $E C S(10 \mathrm{~d})$ was administered, and brain sections were subjected to immunohistochemical analysis using an antibody specific for CREB. Representative autoradiograms are shown; equivalent results were obtained from 4 rats examined in each treatment group.

over, levels of CREB mRNA were increased by chronic administration of several different classes of antidepressants with different acute actions, including both 5-HT- and NE-selective reuptake inhibitors. This suggests that upregulation of CREB may be a common target of 5-HT and NE neurotransmitter systems and antidepressant treatments. In contrast, this effect was not observed after chronic administration of several nonantidepressant psychotropic drugs (i.e., cocaine, morphine, and haloperidol), demonstrating that upregulation of CREB in hippocampus is specific to antidepressants. The lack of regulation by cocaine, which also blocks the reuptake of 5-HT and NE, could be explained by additional effects of this drug that oppose the expression of CREB, or by additional actions of antidepressants that are required for induction of CREB. Alternatively, the rapid metabolism of cocaine relative to antidepressants would result in drug levels that are pulsatile, whereas regulation of CREB may require sustained drug levels and sustained blockade of 5-HT and/or NE reuptake that occurs with antidepressants. In either case, opiates and psychostimulants are reported to regulate the expression and/or phosphorylation of CREB in other brain regions, indicating that CREB may subserve some of the transcriptional actions 

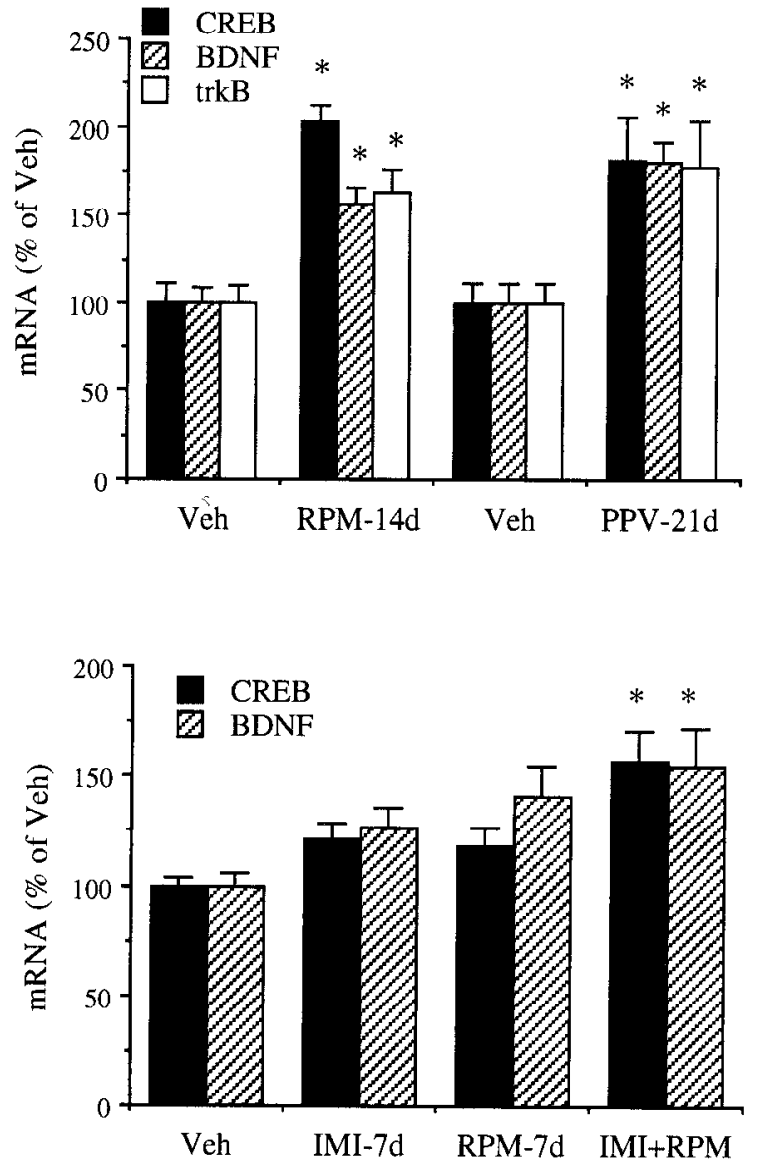

Figure 6. Influence of PDE inhibitors on expression of CREB, BDNF, and trkB mRNA in hippocampus. Top, The influence of chronic rolipram $(R P M ; 2 \mathrm{mg} / \mathrm{kg}$ for $14 \mathrm{~d})$ or papaverine $(P P V ; 10 \mathrm{mg} / \mathrm{kg}$ for $21 \mathrm{~d})$ administration on levels of CREB, BDNF, and trkB mRNA was determined by Northern blot analysis. Bottom, Rats were administered imipramine $(I M I ; 15 \mathrm{mg} / \mathrm{kg})$ and $R P M(10 \mathrm{mg} / \mathrm{kg})$ either alone or in combination for $7 \mathrm{~d}$, and levels of CREB and BDNF mRNA were determined. The results are expressed as percent of vehicle and are the mean \pm SEM of 6 separate rats. ${ }^{*} p<0.05$ compared with vehicle control (top, Student's $t$ test; bottom, ANOVA and Fisher's test).

of these nonantidepressant drugs, but in a region-specific manner (Konradi et al., 1994; Widnell et al., 1994; Cole et al., 1995).

Levels of CRE binding in extracts of hippocampus were also increased by chronic administration of the antidepressants fluoxetine and ECS. The presence of CREB in the CRE binding complex of both sham- and ECS-treated hippocampal extracts was confirmed by demonstrating that preincubation with anti-CREB, but not anti-CREM, antisera disrupted the binding complex. Increased levels of CRE binding indicate that the amount of CREB protein is increased by these treatments, because binding to the symmetrical CRE site (used in this study) is not regulated by the phosphorylation state of CREB (Meyer and Haebner, 1993; Ghosh and Greenburg, 1995). This conclusion is also supported by immunohistochemical studies, which demonstrated that chronic flunxetine or FCS administration increases levels of CREB immunoreactivity in the same cell layers of hippocampus as those demonstrating an increase in CREB mRNA (i.e., dentate gyrus granule cell layer and the CA3 and CA1 pyramidal cell layers). Taken together, the results indicate that the induction of CREB mRNA is accompanied by a corresponding increase in the expression and function of CREB protein.
Although CREB was originally thought to be constitutively expressed and its function controlled primarily by its phosphorylation (Meyer and Haebner, 1993; Ghosh and Greenberg, 1995), recent studies demonstrate that $\mathrm{CREB}$ expression is also subject to regulation (Meyer et al., 1993; Widnell et al., 1994, 1995). The finding that chronic administration of a PDE inhibitor (i.e., rolipram or papaverine) also increases levels of CREB mRNA indicates that the cAMP cascade plays a role in regulation of CREB expression. Indeed, the $5^{\prime}$-flanking region of the human CREB gene contains a CRE that is regulated by cAMP (Ruppert et al., 1992; Meyer et al., 1993). Expression of CREB in sertoli cells is also reported to be increased by activation of the cAMP system (Waeber et al., 1991; Ruppert et al., 1992), and we have found that stimulation of the cAMP system increases expression of CREB in C6 glioma cells (our unpublished obscrvations). Expression of CREB is reported to be decreased by activation of the cAMP system in CATH.a cells (Widnell et al., 1994), indicating that regulation of CREB may be cell type-specific (Widnell et al., 1994). Antidepressant regulation of CREB may also be cell-typeor brain region-specific. For example, chronic antidepressant treatment is reported to decrease levels of PKA, indicating that the function of the cAMP cascade and CREB is reduced in this brain region (Melia et al., 1992). In addition, acute exposure of cultured PC12 cells, an adrenal chromaffin cell line, to certain antidepressants is reported to inhibit the activity of CREB (Schwaninger et al., 1995). In this study, antidepressants inhibited the depolarization-induced activation of CREB, an effect that was demonstrated to result from acute blockade of $\mathrm{Ca}^{2+}$ channels. This inhibition of CREB was observed after acute exposure of PC12 cells to antidepressants and has not been demonstrated in vivo, where other actions of the antidepressant drugs would be expected to predominate over blockade of $\mathrm{Ca}^{2+}$ channels. The results of the present study demonstrate that in the hippocampus the predominant response to administration of a PDE inhibitor, as well as to antidepressant treatments, is upregulation of CREB expression. Antidepressant regulation of CREB (see Fig. 7) could be mediated either by activation of the cAMP cascade (e.g., via $5-\mathrm{HT}_{4,6,7}$ and $\beta$-adrenergic receptors) or by $\mathrm{Ca}^{7+}$-aclivaled protein kinases (e.g., 5 -HT 2 and $\alpha_{1}$-adrenergic receptors), which can also activate CREB (Meyer et al., 1991; Ghosh and Greenburg, 1995).

Increased expression of CREB would be expected to lead to regulation of specific target genes, two of which may be BDNF and trkB. In primary cultures of brain, activation of cAMP- or $\mathrm{Ca}^{2}{ }^{1}$-dependent protein kinases increases the expression of BDNF and trkB (Condorelli et al., 1994; Ghosh et al., 1994). In C6 glioma cells, we have found that activation of the cAMP cascade increases expression of BDNF and trkB mRNA (our unpublished observations). The results of the present study, as well as a previous report from this laboratory (Nibuya et al., 1995), demonstrate that the time course and regional distribution observed for antidepressant regulation of CREB correspond to those for regulation of BDNF and trkB mRNA. In addition, chronic administration of the PDE inhibitors increased levels of mRNA for BDNF and trkB. Although it is extremely difficult to demonstrate directly that expression of a gene in vivo is mediated by a specific transcription factor, the results of the present study are consistent with the possibility that induction of BDNF and trkB are mediated by CREB. This possibility is supported by studies demonstrating that local infusion of CREB antisense, but not sense, oligonucleotide decreases basal and ECS-induced BDNF mRNA levels in hippocampus (Nibuya et al., 1994; Duman 


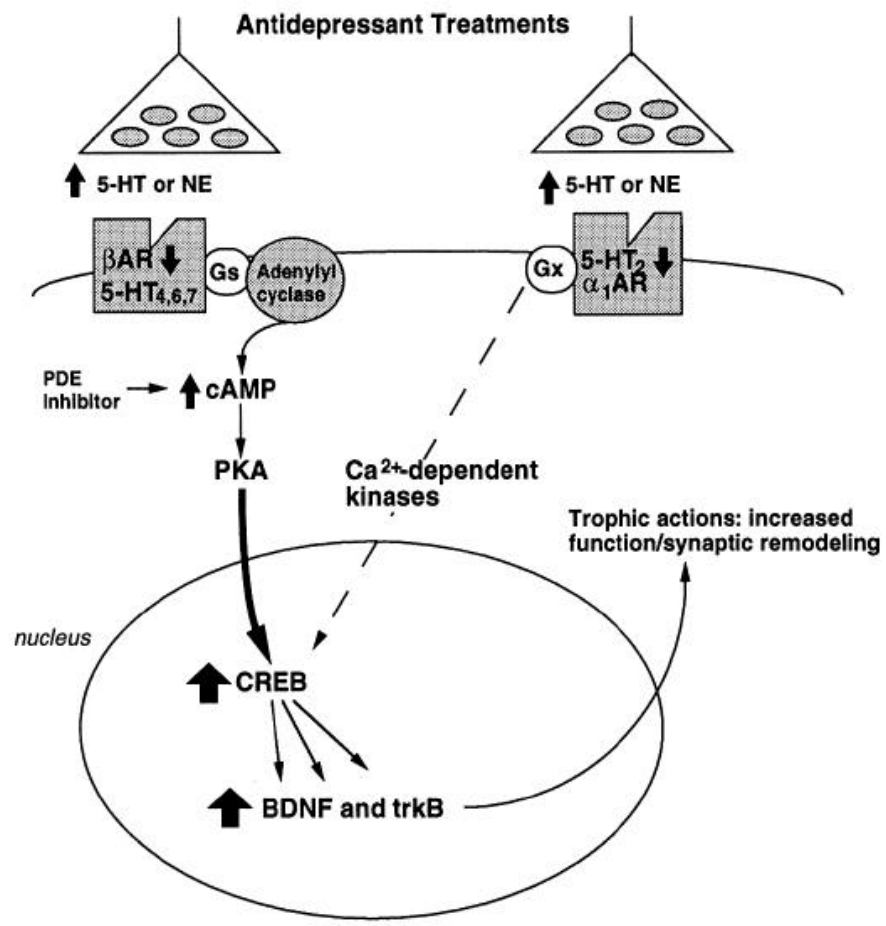

Figure 7. Model of the action of chronic antidepressant treatments on 5-HT and NE receptor-coupled signal transduction pathways and CREB. The results of this study support the hypothesis that CREB is a common target of different types of antidepressant treatments and the 5-HT and NE neurotransmitter systems. CREB could be activated by monoamine receptors that couple to the cAMP-PKA cascade (e.g., 5-HT ${ }_{4,6,7}$ and $\beta$ AR) or via receptors that lead to activation of $\mathrm{Ca}^{2+}$-dependent kinases (e.g., 5- $\mathrm{HT}_{2}$ and $\alpha_{1} \mathrm{AR}$ ). Although chronic treatments may lead to downregulation of 5-HT and NE receptors, the results of the present study demonstrate that the expression and function of CREB are increased, indicating that the functional output of these systems is upregulated, not downregulated, by chronic antidepressant administration. This conclusion is supported further by results demonstrating that levels of BDNF and trkB, two potential targets of CREB, are increased by chronic antidepressant treatment. Upregulation of BDNF and trkB could have autocrine or paracrine actions on hippocampal neurons or neurons innervating this brain region, such as 5-HT neurons. This includes increased neuronal survival, function, and remodeling of synaptic or cellular architecture.

et al., 1995). It is important to point out that regulation of CREB probably leads to regulation of other target genes, which may also play a role in the action of antidepressant treatments. Moreover, it is possible that chronic antidepressant treatments regulate the expression or function of transcription factors in addition to CREB.

The results demonstrate that coadministration of a PDE inhibitor shortens the time required for upregulation of CREB and BDNF expression by imipramine. This interaction could occur if the PDE inhibitor enhances the cAMP response to receptors activated by 5 -HT or NE. Enhancement of the cAMP response could be particularly advantageous if the 5-HT or NE receptors coupled to cAMP are downregulated in response to elevated levels of monoamines, as reported for the $\beta$-adrenergic receptor (Heninger and Charney, 1987; Duman et al., 1994) and the 5-HT receptor (Sleight et al., 1995). Clinical studies are required to determine whether coadministration of a PDE inhibitor is capable of shortening the time required for the therapeutic action of antidepressant treatments.

Increased expression of CREB and induction of BDNF and trkB in response to chronic antidepressant treatments could in- crease the survival and/or function of neurons, as reported for direct application of BDNF (Ghosh et al., 1994; Lindsay et al., 1994; Lindvall et al., 1994). This could include autocrine actions on hippocampal neurons and paracrine actions on neurons that innervate this brain region. Autocrine actions could be of particular importance for cases of depression associated with severe, chronic stress or other types of neuronal insult that decrease BDNF and lead to atrophy and, in severe cases, reduced survival of hippocampal neurons (Sapolsky et al., 1985, 1990; McEwen and Gould, 1990; Watanabe et al., 1992; Stein-Behrens et al., 1994; Smith et al., 1995). Upregulation of BDNF expression in response to antidepressant treatments could thereby enhance the function and survival of hippocampal ncurons. Paracrinc actions of BDNF could include increased function of 5-HT and NE neurons that innervate hippocampus, because BDNF is reported to increase the survival and sprouting of 5-HT neurons (Siuciak et al., 1994b; Mamounas et al., 1995; Sklair-Tavron and Nestler, 1995). This could be important, for example, if in certain cases depression is associated with a reduced capacity to synthesize $5-\mathrm{HT}$. Taken together, the results indicate that 5-HT and BDNF stimulate the expression of each other, and thereby form a positive regulatory loop that may be critical for the function and survival of 5-HT neurons and neurons innervated by $5-\mathrm{HT}$.

The results demonstrate that chronic administration of several different types of antidepressant drugs, as well as ECS, increases the expression and function of CREB, suggesting that this transcription factor is a common intracellular target of antidepressants. The results also support the hypothesis that the 5-HT- and $\mathrm{NE}$ receptor-coupled intracellular cascades that lead to regulation of CREB are activated, not downregulated, by chronic antidepressant treatments (Fig. 7). This suggests that although levels of certain 5-HT and NE receptors (e.g., $\beta$-adrenergic, $5-\mathrm{HT}_{2 \mathrm{~A}}$, and $5-\mathrm{HT}_{7}$ receptors) may be reduced by chronic antidepressant treatments, there is an increase in the functional output of these receptor-coupled intracellular pathways. This is not surprising because the density and function of these receptors are reduced, but not completely eliminated, by chronic antidepressant treatments (Heninger and Charney, 1987). Activation of the remaining 5-HT and NE receptors may be sufficient to stimulate the intracellular signal transduction pathways. This possibility is supported further by the finding that BDNF and trkB, targets of the cAMPCREB cascade, are also increased by chronic antidepressant treatments. Future studies will test this hypothesis further by examining additional antidepressant and nonantidepressant treatments. Moreover, our studies will attempt to elucidate the cellular consequences of the upregulated CAMP-CREB cascade and of increased expression of BDNF and trkB.

\section{REFERENCES}

Bremner JD, Randall P, Scott TM, Bronen RA, Seibyl JP, Southwick SM, Delaney RC, McCarthy G, Charney DS, Innis RB (1995) MRI-based measurement of hippocampal volume in patients with combat-related posttraumatic stress disorder. Am J Psychiatry 152:973-981.

Cole RL, Konradi C, Douglass J, Hyman SE (1995) Neuronal adaptation to amphetamine and dopamine: molecular mechanisms of prodynorphin gene regulation in rat striatum. Neuron 14:813-823.

Condorelli DF, Dell'Albani P, Mudo G, Timmusk T, Belluardo N (1994) Expression of neurotrophins and their receptors in primary astroglial cultures:induction by cAMP elevating agents. J Neurochem 63:509-516.

Duman RS, Heninger GR, Nestler EJ (1994) Adaptations of receptorcoupled signal transduction pathways underlying stress- and druginduced neural plasticity. J Nervous Mental Dis 182:692-700.

Duman RS, Vaidya VA, Nibuya M, Morinobu S, Rydelek Fitzgerald L (1995) Stress, antidepressant treatments, and neurotrophic factors: molecular and cellular mechanisms. The Neuroscientist 1:351-360. 
Fitzgerald RL, Vaidya VA, Terwilliger RZ, Duman RS (1995) Electroconvulsive scizure increases the expression of CREM (cAMP response element modulator) and ICER (inducible cAMP early repressor) in rat brain. J Ncurochem 66:429-432.

Ghosh A, Greenberg ME (1995) Calcium signaling in neurons: molecular mechanisms and cellular consequences. Science 268:239-247.

Ghosh A, Carnahan J, Greenberg ME (1994) Requirement for BDNF in activity-dependent survival of cortical neurons. Science 263:1618-1623.

Heninger GR, Charney DS (1987) Mechanisms of action of antidepressant treatments: Implications for the etiology and treatment of depressive disorders. In: Psychopharmacology: the third generation of progress (Meltzer HY, ed), pp 535-544. New York: Raven.

Hudson CJ, Young LT, Li PP, Warsh JJ (1993) CNS signal transduction in the patho-physiology and pharmacotherapy of affective disorders and schizophrenia. Synapse 13:278-293.

Jacobson L, Sapolsky R (1991) The role of the hippocampus in feedback regulation of the hypothalamic-pituitary-adrenocortical axis. Endocrine Rev 12:18-134.

Konradi C, Cole RL, Heckers S, Hyman SE (1994) Amphetamine regulates gene expression in rat striatum via transcription factor CREB. J Neurosci 14:5623-5634.

Lindsay RM, Wiegand SJ, Anthony Altar CA, DiStefano PS (1994) Neurotrophic factors: from molecule to man. Trends Neurosci 17:182-190.

Lindvall O, Kokaia Z, Bengzon J, Elmer E, Kokaia M (1994) Neurotrophins and brain insults. Trends Neurosci 17:490-496.

Maes M, Meltzer HY (1995) The serotonin hypothesis of depression. In: Psychopharmacology: the fourth generation of progress (Bloom FE, Kupfer DJ, eds), pp 933-944. New York: Raven.

Mamounas LA, Blue ME, Siuciak JA, Anthony Altar C (1995) BDNF promotes the survival and sprouting of serotonergic axons in the rat brain. J Neurosci 15:7929-7939.

McEwen BS, Gould E (1990) Adrenal steroid influences on the survival of hippocampal neurons. Biochem Pharmacol 40:2393-2402.

Melia KR, Rasmussen K, Haycock J, Terwilliger RZ, Nestler EJ, Duman RS (1992) Coordinate regulation of firing rate, tyrosine hydroxylase, and the cyclic AMP system in rat locus coeruleus: effects of chronic stress and norepinephrine depleting agents. J Neurochem 58:494-502.

Menkes DB, Rasenick MM, Wheeler MA, Bitensky MW (1983) Guanosine triphosphate activation of brain adenylate cyclase: enhancement by long-term antidepressant treatment. Science 129:65-67.

Meyer TE, Habener JF (1993) Cyclic adenosine 3',5'-monophosphate response element binding protein (CREB) and related transcriptionactivating deoxyribonucleic acid-binding proteins. Endocrine Rev 14:269-290.

Meyer TE, Waeber G, Lin J, Beckman W, Haebner JF (1993) The promoter of the gene encoding $3^{\prime}, 5^{\prime}$-cyclic monophosphate (cAMP) response element binding protein contains cAMP response elements: evidence of positive autoregulation of gene transcription. Endocrinology 132:770-780.

Nestler EJ, Terwilliger RZ, Duman RS (1989) Chronic antidepressant administration alters the subcellular distribution of cyclic AMP-dependent protein kinase in rat frontal cortex. J Neurochem 53:1644-1647.

Nibuya M, Rydelek Fitzgerald L, Russell DS, Nestler EJ, Duman RS (1994) Induction of BDNF and trkB by electroconvulsive seizure: regional regulation and role of CREB. Soc Neurosci Abstr 24:1312.

Nibuya M, Morinobu S, Duman RS (1995) Regulation of BDNF and trkB mRNA in rat brain by chronic electroconvulsive seizure and antidepressant drug treatments. J Neurosci 15:7539-7547.

Ozawa H, Rasenick MM (1991) Chronic electroconvulsive treatment augments coupling of the GTP-binding protein Gs to the catalytic moiety of adenylyl cyclase in a manner similar to that seen with chronic antidepressant drugs. J Neurochem 56:330-338.

Perez J, Tinelli D, Brunello N, Racagni G (1989) cAMP-dependent phosphorylation of soluble and crude microtubule fractions of rat ce- rebral cortex after prolonged desmethylimipramine treatment. Eur J Pharmacol 172:305-316.

Ruppert S, Cole TJ, Boshart M, Schmid W, Schutz G (1992) Multiple mRNA isoforms of the transcription factor CREB: generation by alternative splicing and specific expression in primary spermatocytes. EMBO J 11:1503-1512.

Sapolsky RM, Krey LC, McEwen BS (1985) Prolonged glucocorticoid exposure reduces hippocampal neuron number: implications for aging. J Neurosci 5:1222-1227.

Sapolsky RM, Uno H, Robert CS, Finsh CE (1990) Hippocampal damage associated with prolonged glucocorticoid exposure in primates. J Neurosci 10:2897-2902.

Schatzberg AF, Schildkraut JJ (1995) Recent studies on norepinephrine systems in mood disorders. In: Psychopharmacology: the fourth generation of progress (Bloom FE, Kupfer DJ, eds), pp 911-920. New York: Raven.

Schwaninger M, Schoel C, Blume R, Rossig L, Knepel W (1995) Inhibition by antidepressant drugs of cyclic AMP response element-binding protein/cyclic AMP response element-directed gene transcription. Mol Pharmacol 47:1112-1118.

Siuciak JA, Lewis D, Wiegand SJ, Lindsay RM (1994a) Brain derived neurotrophic factor (BDNF) produces an anti-depressant like effect in two animal models of depression. Soc Neurosci Abstr 20:1106.

Siuciak JA, Anthony Altar CA, Wiegand SJ, Lindsay RM (1994b) Antinociceptive effect of brain-derived neurotrophic factor and neurotrophin-3. Brain Res 633:326-330.

Sklair-Tavron L, Nestler EJ (1995) Opposing effects of morphine and the ncurotrophins, NT-3, NT-4, and BDNF, on locus cocruleus neurons in vitro. Brain Kes 702:117-125.

Sleight AJ, Carolo C, Petit N, Zwingelstein C, Bourson A (1995) Identification of 5-hydroxytryptamines 7 receptor binding sites in rat hypothalamus: sensitivity to chronic antidepressant treatments. Mol Pharmacol 47:99-103.

Smith MA, Makino S, Kvetnansky R, Post RM (1995) Stress alters the express of brain-derived neurotrophic factor and neurotrophin-3 $\mathrm{mR}$ NAs in the hippocampus. J Neurosci 15:1768-1777.

Stcin-Bchrens B, Mattson MP, Chang I, Yeh M, Sapolsky R (1994) Stress exacerbates neuron loss and cytoskeletal pathology in the hippocampus. J Neurosci 14:5373-5380.

Sulser F (1989) New perspectives on the molecular pharmacology of affective disorders. Psychol Sci 238:231-239.

Uno H, Tarara R, Else JG, Suleman MA, Sapolsky RM (1989) Hippocampal damage associated with prolonged and fatal stress in primates. J Neurosci 9:1705-1711.

Waeber G, Meyer TE, LeSieur M, Hermann HL, Gerard N, Haebner JF (1991) Developmental stage-specific expression of cyclic adenosine $3^{\prime}, 5^{\prime}$-monophosphate response clement-binding protein CREB during spcrmatogenesis involves alternative exon splicing. Mol Endocrinol $5: 1418-1430$

Watanabe Y, Gould E, McEwen BS (1992) Stress induces atrophy of apical dendrites of hippocampal CA3 pyramidal neurons. Brain Res 588:341-345.

Widnell KL, Russell DS, Nestler EJ (1994) Regulation of expression of cAMP response element-binding protein in the locus coeruleus in vivo and in a locus coeruleus-like cell line in vitro. Proc Natl Acad Sci USA 91:10947-10951.

Widnell KL, Self DW, Lane SB, Russell DS, Vaidya VA, Miserendino MJD, Rubin CR, Duman RS, Nestler EJ (1996) Regulation of CREB cxpression: in vivo cvidence for a functional rolc in morphine action in the nucleus accumbens. J Pharmacol Exp Ther 276:306-315.

Young EA, Haskett RF, Murphy-Weinberg V, Watson SJ, Akil H (1991) Loss of glucocorticoid fast feedback in depression. Arch Gen Psychiatry 48:693-699. 